\title{
Facilitating Leader Tacit Knowledge Acquisition
}

\author{
Matošková Jana, Reháckevá Helena, Sobotková Eliškea, \\ Polcáková Martina, Jurásek Martin, Gregar Alešs, Švec Vlastimil
}

\begin{abstract}
The aim of the paper is to identify how to support the moulding of tacit knowledge which is necessary for success in a managerial position within a framework for the preparation and development of managers. The paper is based on an analysis of expert publications and the results of a completed project. Research respondents and theorists agree with the necessity for active involvement of trainees. It is also important to develop knowledge within the framework of manager preparation with significant reflection on learning from mistakes. From the methods of tacit knowledge transfer a close collaboration with experienced people, working in teams, training of model situations, goal-directed interviews, coaching, job rotation, short term attachments and excursions seem to be the most beneficial. It is also important to pay attention to the cultivation of organisational culture, especially in the sense of accepting knowledge sharing as the norm.
\end{abstract}

Key words: Tacit Knowledge, Professional Education, Manager Preparation, Tacit Knowledge Acquisition, Knowledge Transfer

\section{INTRODUCTION}

People in organisations have a potential competitive advantage. Folwarczná (2010) says that the way in which managers of organisations deal with their subordinates influences how employees communicate with customers and with the interests of employees in looking for innovations and solutions. Manager's skills, knowledge, their involvement and their managerial style are from the point of organisation competitiveness very important factors. If managers are to fulfil their role successfully they should be well prepared. This is why many expert publications are aimed at manager preparation, development and education. This topic is always lively discussed.

Scientists, e.g. Sternberg (1997), Eraut (2000), Kerr (1995), Armstrong and Mahmud (2008), have shown that a factor which decides if managers will be successful in their profession or not is tacit knowledge. Our paper is focused on this topic. The aim of the paper is to identify how to support the forming and moulding of tacit knowledge which managers will need in their work within the framework of manager preparation.

The paper is based on the content analysis of expert publications and the results of a completed project. In the first part theoretical backgrounds will be presented, next the research results followed by a discussion part. 


\section{THEORETICAL BACKGROUNDS}

The paper is aimed at managers, that is employees who are responsible for the fulfilment of tasks connected with managing other people ("Manažer a jeho role 1.," 2009). According to Folwarczná (2010) a manager is responsible for the organisation or duties no matter if it is a business, public administration, social or a non-profit organisation. The manager's tasks are managing, planning some actions, organising, delegating tasks and checking their fulfilment (Hurych, n.d., "Průvodce světem povolání - Manažer," n.d.). Truneček (2002) claims that we need to prepare managers who are universally educated, with a broad scope, innovative and permanently learning. Prokopenko et al. (1996) maintain the idea that the educational methods used should be active rather than passive. Additionally the education process should be, according to Prokopenko et al. (1996), as close to the manager's actions in the real (business) environment as possible in content and method.

The key term of the paper is tacit knowledge. There are several definitions of tacit knowledge. E.g. Bishop (2003) defines tacit knowledge as what we know about what we do. Choi (2001) understands it as an automatic, often intuitive action or reaction to concrete circumstances. Generally we can define tacit knowledge as practical know-how, which is formed in the minds of people in the course of time on the basis of experience and interactions with their surroundings. The individual is not often aware of it because they gain it without conscious attention and use it spontaneously. There is an obvious connection with routine actions, which Pacovský (2006) specifies, because tacit knowledge is stored in our sub-consciousness and it has a tendency to be activated when an incentive appears. Tacit knowledge is connected with a setting understanding and according to Baumard (1996) it helps the individual to orientate in ambiguous situations. Wagner and Sternberg (1992) distinguish three categories of tacit knowledge - tacit knowledge about self-management (intrapersonal), tacit knowledge about managing others (interpersonal), and tacit knowledge about task managing which is context specific.

\subsection{Tacit Knowledge Transfer}

Tacit knowledge is often unsuspected and additionally its explication in the form of words, numbers or symbols is not easy and often not even possible - see e.g. Matošková (2008, pp. 43-44) - tacit knowledge teaching and its transfer in itself is difficult. Furthermore, to transfer tacit knowledge which would be completely consistent with the original is often not possible - everyone forms their own tacit knowledge on the basis of their previous experience, knowledge, skills and mental models - see e.g. Mládková (2008), Athanassiou and Nigh (2000). However a well-prepared development programme can at least make tacit knowledge forming faster or can create in the mind of the individual some receptors which could make tacit knowledge forming and moulding easier.

First of all for tacit knowledge teaching, suitable methods must be chosen (see chapter 2.1.1). Hendrich et al. (2000) say it is important to combine learning in both formal and informal contexts. According to Choi (2001) students must be encouraged to think and to consider what to do, to find a solution. This is connected with the statement that the methods used must support the reflection of trainees as claimed by Torff and Sternberg (1998) and Yeh et al. (2012). According to Torff and Sternberg (1998) it is advisable to build on any previous knowledge of students in tacit knowledge teaching. 
Armstrong (2001) says that the educational plan for tacit knowledge teaching must be consistent with specific circumstances in which tacit knowledge will be used as much as possible.

Authors - e.g. Haldin-Herrgärd (2000), Lindley and Wheeler (2001), Howells (1996), Mládková (2005) - agree that time is also necessary for tacit knowledge transfer and forming. This is because the trainee must absorb the knowledge. Mládková (2005) warns that it is not possible to expect a work-loaded individual to be able and willing to give their time to new knowledge. The fact that the trainee has absorbed the knowledge and understands it should be checked by the owner of the original knowledge.

For the successful transfer of tacit knowledge, according to Mládková (2005, p. 142), it is important that bilateral knowledge fits the specific context. This means that the efficiency of the tacit knowledge used is influenced by context, concrete circumstances and the setting. In another context the effort to use the same knowledge may be a bad decision.

Reciprocal understanding (good interpersonal relationships, reciprocal trust, and reciprocal respect) between the involved participants, empathy, patience and their flexibility are also very important. Reciprocal understanding, as we can deduce from the literature of Mládková (2005), Haldin-Herrgärd (2000), Endres, Endres, Chowdhury, and Alam (2007), Kothuri (2002), Breschi and Lissoni (2001), Gertler (2002), arises more easily if participants are in physical proximity (much knowledge is transferred not only verbally but also with nonverbal communications for example in contact face-to-face). Furthermore, personal contact gives the "teacher" a better possibility of checking the knowledge absorption, to check if the trainee understands the knowledge correctly. A social proximity is important too. The social proximity of shared values, norms, conventions, shared culture and a close understanding which can arise from shared work or study experiences or previous collaboration. Many of which required face-to-face contact and a high degree of socialisation and the closeness survived until the end of the co-operation. $\mathrm{Mu}$ tual understanding contributes to the willingness for mutual communication. It also decreases communication barriers for example a fear of stultification or misunderstanding and fears of misusing knowledge. In this way it supports a successful knowledge transfer.

Organisations themselves can support tacit knowledge transfer by setting suitable conditions and mechanisms for knowledge sharing. Suitable conditions can be achieved by the cultivation of organisational culture, focusing on the support and development of motivation to knowledge spreading and discharging fears of improper knowledge spreading plus offering formal and informal opportunities for knowledge sharing. For example Endres, Endres, Chowdhury, and Alam (2007) claim that employees have a tendency to knowledge sharing when they have a feeling that organisational norms contain only knowledge sharing and nothing more. Knowledge sharing support is discussed further for example in Matošková (2012).

Prokopenko et al. (1996) note that none of the educational methods in themselves guarantee that learning will really happen - it depends on special interest, will and the abilities of each participant. Motivation of an individual remains crucial. With this claim the opinions of Mládková (2005), Collison and Parcel (2005) are consistent.

\subsubsection{Methods of Knowledge Transfer}

With the choice of methods for tacit knowledge transfer and its teaching the importance of learning from experience is often emphasised - e.g. Penger, Znidarsic, and Dimovski (2011), Armstrong andMahmud (2008). 
With regard to knowledge transfer and future manager preparation, the following methods are basic (see e.g. Collison \& Parcell, 2005, Krogh, Ichijo, \& Nonaka, 2000, Fetterhoff, Nila, \& McNamee, 2011, Gertler, 2002, Howells, 1996, Mládková, 2004, Mládková, (2005), Sveiby, 1997, Talisayon, 2003, Athanassiou \& Nigh, 2000, Torff \& Sternberg, 1998, Vymětal, Diančiková, \& Váchová, 2005):

- A close collaboration with an experienced person (assisting, apprenticeship, mentoring, and patronage) - in the framework of this method knowledge sharing happens on the basis of personal contact and observation of work done by an experienced individual. The observation can be supplemented with questions like "how" and "why", discussion and imitation, the usage of traced ways of work and ways of solving problems in practice.

- Work in teams and communities - intergenerational teams are ideal.

- Training of model situations (simulations), including the usage of computer simulations.

- Case-study solving.

- Goal-target interviews - e.g. with important workers in the organisation and with workers who are retiring.

- Meetings connected especially with preparation, realisation or surveys of projects (briefing, debriefing, assistant meeting, retrospection and after action review).

- Experience and knowledge presentation to others - e.g. in the form of a presentation of own failure in a given quarter, the success of a given month, or the introduction of an interdomain forum and meeting, the formation of so-called despatch for future employees, telling stories and experiences, collective breakfast or lunch, sharing so-called best practices.

- Coaching.

- Job rotation.

- Short term attachments and excursions.

- Work with a so-called knowledge database of the organisation.

\section{RESEARCH METHODS}

The aim of the project which was practised in our university from 2008 to 2010 was to gain knowledge about managerial tacit knowledge and the possibilities of its development. In the framework of the project, 32 interviews with managers and 4 discussion groups were initiated.

The choice of managers was a simple purposeful choice. Among the respondents there were 26 men and 6 women. Their average age was approximately 50 years and they had been in manager positions on average for almost 18 years.

Ten of the interviews were inspired by the methods presented by Haldin-Herrgärd (2003). All were given 17 theme cards which are sometimes used by non-experts to label tacit knowledge, for example subconscious, emotion, intuition, experience, common sense, talent, creativity, curiosity, skills and abilities, perception and beliefs, all of which describe factors which may have an influence on tacit knowledge formation. Prepared examples included organisational culture, learning from mistakes and faults, life examples and models, knowledge sharing, self-management and mentor with teacher relations. Participants were asked to choose the cards which are connected to managerial work. They then explained what connection they could see. The average length of the interviews was 45 minutes. 
Next, 12 interviews with other managers were focused on important events in their professional careers, their professional objectives, the importance of a mentor and their way of working. The interviews lasted on average 36 minutes.

For the final set of interviews the inspiration came from the methods of Österåker (2001). 24 abstract terms connected with managerial work were chosen including organisation culture, knowledge sharing, learning from mistakes, intuition and sub-consciousness. All of these terms were symbolised by a picture which was chosen after a team discussion of project members. Participants were asked to interpret their picture in relation to a manager's work. The average length of the interviews was 27 minutes.

For the discussion groups, academics and practitioners were invited. The topic of the meetings was tacit knowledge development and sharing in firms, knowledge of workers and their management, tacit knowledge formation, transfer and externalisation plus Tacit knowledge of managers and its development. Ten people took part in the first discussion group (4 managers and 6 academics); nine participants were in the second group ( 7 practitioners, especially HR managers and 2 academics). Eleven academics participated in the third group and finally

7 people (6 academics and 1 practitioner) took part in the final group.

Records of the interviews and discussion groups were transcribed. The transcriptions were analysed with the use of so-called methods of pattern recognition (looking for and noticing patterns, topics and structures which are repeated in data) and the factor method (looking for factors which are not directly observable but have an implicit character and influence a certain phenomenon or a situation etc.). In total 1,733 quotations were identified in the transcriptions. These were then coded from 182 chosen codes by a team discussion of project members. Finally, 1,515 links among the codes were found in the text content analysis.

The types of links that were used are in the Tab. 1.

Tab. 1 - Types of links among codes. Source: own

\begin{tabular}{|c|c|c|c|c|c|}
\hline ID & Label 1 & Label 2 & Menu & Width & Type \\
\hline ASSO & $=$ & $R$ & is associated with & 1 & symmetric \\
\hline BTP & [] & G & is part of & 2 & transitive \\
\hline CAUSA & $\Rightarrow>$ & $N$ & is cause of & 1 & transitive \\
\hline CONTRA & $\langle>$ & A & contradicts & 1 & symmetric \\
\hline INF & $>>$ & I & is influencing & 1 & asymmetric \\
\hline INFLU & $>>$ & I & is influencing & 1 & asymmetric \\
\hline ISA & isa & 0 & is a & 3 & transitive \\
\hline NONAME & & & noname & 1 & symmetric \\
\hline PROP & *\} & $\mathrm{P}$ & is property of & 1 & asymmetric \\
\hline
\end{tabular}

\section{RESEARCH RESULTS AND THEIR INTERPRETATION}

The research confirms that tacit knowledge is based on experiences; it is influenced by data and information which the individual has gained in the past as well as by personal characteristics and the skills of an individual. Tacit knowledge is also closely connected with context and situation understanding. Tacit knowledge formation and moulding can be facilitated by suitable conditions in the surrounding environment. Theoretical knowledge can make a person more sensitive and perceptive to specific incentives and so facilitate tacit knowledge formation. 
In managerial work tacit knowledge especially influences the choice of team or work-group members and activities connected with team or work-group management. Tacit knowledge also deals with activity planning and organisation, the choice of methods and ways of motivating and stimulating subordinates plus the approach to and the way of performance management of employees. It is also connected with a manager's self-management, their self-organisation, selfmotivation and self-control.

The initial step in a manager's preparation should be, according to research results, identification of individual potential for a managerial position. Important qualifications for managers seem to be: creativity, diligence, ambitions, organisational skills, humility, perception, intelligence and curiosity. When respondents mentioned humility, they appealed especially to new graduates: "Graduates must comprehend that practice is often a totally different experience and there are situations in which the school is not able to prepare them." "They should not think: I have a diploma, I have the credentials so now I am the cleverest man" (paraphrased).

For a manager's preparation the necessity for the active involvement of the trainee in the process was emphasised as well as teachers having experience from practice.

The results of manager preparation should be, according to respondents, an understanding of the processes and their cohesion in firms, a comprehension of where to look for a solution and how to progress, a comprehension that practice is not black-and-white and so to give up on efforts to apply theoretical theses at any cost into practice. Simultaneously, future managers should develop their strengths within the framework of a manager's preparation and development. Potential managers need to broaden their knowledge including language knowledge, specialist knowledge and general insight. These were mentioned as important and skills connected especially with team management. Managers must comprehend team roles, team management principles and methods of initiation in teams. Motivation is important so they should develop their emotional and social intelligence and their communication in active listening, persuading principles, presentation skills, assertiveness, negotiation and giving feed-back. It is also important to develop their analytical skills and the ability to use so-called common sense. Obviously managers should be able to manage work with a P.C. and with information and communication technologies. They must also learn to set priorities and develop their organisational skills. It is also necessary for the trainee to understand themselves so to comprehend which methods and techniques are suitable for them. Further, how to learn to be motivated themselves and how to manage their emotions. The preparation should also be focused on the cultivation of manager's attitudes. The respondents mentioned customer orientation, an understanding for the necessity of whole-life-development and a positive attitude to ethics. A part of managerial preparation should also be the development of positive characteristics for the future manager including, curiosity, perception, creativity, hard-work, responsibility and a riddance of bad habits.

According to respondents a sequential preparation is important including practice and gradually gaining experience especially experience connected with people management. One of the respondents said: "Boys and girls taking whatever position, no matter if it is in a Church or among fire-fighters, they must learn to communicate so to be able to get along with people and to be able to gain their confidence. Otherwise they cannot manage people. Otherwise people will not trust them. This experience is not possible to gain from a book but from attack - from interaction" (paraphrased). Benefits from sequential career management are, according to respondents, 
a reduction of mistakes, their quantity as well as their consequences, acclimatisation to stress, learning how to deal with failure, understanding the work of future subordinates and learning how to communicate in a way which will be understandable for their future subordinates.

According to some respondents, it is advisable to attest an adept manager by a challenging situation or a complex project, because learning from their own or other's mistakes is important. It is beneficial for managerial development to solve model situations, to coach to target models of behaviour and to be inspired by them. The co-operation of someone who is experienced is also advisable ("I would advise young managers to follow senior managers who will lead them somehow to replace them one day but who will not keep information only for themselves and will not see a trainee as a rival." Paraphrased), whether within the framework of mentoring, team work or at least the possibility for discussion with them. More experienced managers could especially draw attention to the impact of behaviour and decision making.

If the period of managerial preparation is underestimated there is a risk, with the words of one of our respondent, of the following: “.... suddenly, the image of the manager position gets into their head and the trainee changes their style of behaviour so it is no longer about participation but about directions and then they do not manage their emotions..." (Paraphrase).

Further, the provision of a suitable background is important, e.g. the provision of technics, access to information sources including systems of looking for and processing data.

Fig. 1 (see Apendix I) presents identified links of the code "manager preparation" to others codes. For a better understanding of the code links a list of connections is enclosed (see Appendix II).

\section{DISCUSSION}

The research results are in compliance with results of other authors. Experiences as the base for tacit knowledge formation is presented e. g. by Brockmann and Anthony (2002), Germain and Quinn (2005), Liao (2005). A connection between tacit knowledge and context is stated e. g. by Jones, Failla and Miller (2007), Matthew and Sternberg (2009), Wasonga and Murphy (2006). The importance of tacit knowledge in managerial work is mentioned e. g. by Brockmann and Simmonds (1997), Germain and Quinn (2005), Janson and McQueen (2007), Nestor-Baker and Hoy (2001).

Research respondents as well as academics have found a consensus which is of necessity for the active involvement of a trainee. The importance lies in knowledge development and in reflection, especially in the sense of learning from mistakes.

The mentioned results of manager preparation in chapter 4 are closely connected with creating and cultivating tacit knowledge in future managers. This corresponds with the insistence which was put into context by respondents. In regard to tacit knowledge classification, the mentioned classification of Wagner and Sternberg (1992) seems acceptable. According to our research however the main role in managerial work is played by tacit knowledge connected with people management, interpersonal tacit knowledge.

From methods of tacit knowledge transfer (see chapter 2.1.1) respondents spontaneously mentioned in reaction to questions about managerial development the following principle: a close collaboration with an experienced person, team work, training in model situations, goal-target 
interviews, coaching, job rotation, short term attachments and excursions. Therefore it seems that these education methods should be an integral part of systematic preparation for future managers in all organisations including schools and universities.

We think that the main barrier in tacit knowledge development for future managers will neither be a definition, as a part of preparation nor a choice of suitable methods of knowledge transfer. The main problem will probably be to find individuals who have the appropriate tacit knowledge and are willing to share it. In regard to this, it seems vital to aim at organisational culture cultivation, to emphasise and integrate a norm that knowledge sharing is welcomed, necessary and beneficial for all participants. Managers have an important role in organisations and their decisions could be an example of this.

\section{CONCLUSION}

The aim of the paper was to identify how to facilitate tacit knowledge forming in the framework of manager preparation. First of all it is necessary to be aware, that it is important to focus on this part of managerial development and that tacit knowledge is connected not only with a realisation of given tasks but also with managing others as well as with self-management. Furthermore, an individual or people who have tacit knowledge and are motivated, or at least stimulated, by its transfer should be chosen. Then suitable methods of knowledge transfer must be chosen and enough time given for tacit knowledge integration in the mind of the trainee.

We believe that tacit knowledge development of future managers and other employees is important, so we have decided to continue in our research. Our attention is drawn now to the tacit knowledge of those who will join the labour market in the near future, that is students from universities. This task is connected with our idea that if we want to develop something. We should first be able to identify it somehow and then to measure it. As yet tacit knowledge measurement is not well explored. Students are as research respondents accessible and we hope they will be willing to co-operate. GA ČR (Czech Science Foundation) grant-maintained project, Reg. No. 407/12/0821, started in January 2012 and will finish in December 2014.

\section{Acknowledgements}

This contribution was written within the framework of the GA ČR (Czech Science Foundation) grant-maintained project: Reg. No. 407/12/0821, Creating a Czech Instrument for Measuring Academic Tacit Knowledge, and with the financial support of GA ČR.

\section{References}

1. Armstrong, S. (2001). How can tacit knowledge and intuition be cultivated in oneself and others? Retrieved from http://www.gse.harvard.edu/ t656_web/From_2000-2001_ students/how_can_tki_be_cultivated_in_one.htm

2. Armstrong, S. J. \& Mahmud, A. (2008). Experiential Learning and the Acquisition of Managerial Tacit Knowledge. Academy of Management Learning \& Education, 7(2), 189-208. http://dx.doi.org/10.5465/AMLE.2008.32712617

3. Athanassiou, N. \& Nigh, D. (2000). Internationalization, Tacit Knowledge and the Top Management Teams of MNCs. Journal of International Business Studies, 31(3), 471-487. http:// dx.doi.org/10.1057/palgrave.jibs.8490917

4. Baumard, P. (1996). Organizations in the Fog: An Investigation into the Dynamics of 
Knowledge. In Organizational Learning and Competitive Advantage (Bertrand Moingeon and Amy Edmondson., pp. 74 - 91). London: Sage.

5. Bishop, K. (2003). So, you'd like to manage knowledge? Retrieved October 14, 2003, from http://www.oneumbrella.com.au/reports/knowledge/manage.html

6. Breschi, S. \& Lissoni, F. (2001). Localised knowledge spillovers vs. innovative milieux: Knowledge "tacitness" reconsidered. Papers in Regional Science, 80(3), 255-273. http://dx.doi. org/10.1007/PL00013627

7. Brockmann, E. N. \& Anthony, W. P. (2002). Tacit Knowledge and Strategic Decision Making. Group \& Organization Management, 27(4), 436-455. http://dx.doi.org/10.1177/10596 01102238356

8. Brockmann, E. N. \& Simmonds, P. G. (1997). Strategic Decision Making: The Influence of CEO Experience and Use of Tacit Knowledge. Journal of Managerial Issues, 9(4), 454-467.

9. Collison, C. \& Parcell, G. (2005). Knowledge management. Brno: Computer Press.

10. Endres, M. L., Endres, S. P., Chowdhury, S. K. \& Alam, I. (2007). Tacit Knowledge Sharing, Self-Efficacy Theory, and Application to the Open Source Community. Journal of Knowledge Management, 11(3), 92-103. http://dx.doi.org/10.1108/13673270710752135

11. Eraut, M. (2000). Non-Formal Learning and Tacit Knowledge in Professional Work. British Journal of Educational Psychology, 70(1), 113-136. http://dx.doi.org/10.1348/000709900158001

12. Fetterhoff, T., Nila, P. \& McNamee, R. C. (2011). Accessing Internal Knowledge: Organizational Practices That Facilitate the Transfer of Tacit Knowledge. Research Technology Management, 54(6), 50-54.

13. Folwarczná, I. (2010). Rozvoj a vzdělávání manažerů. Praha: Grada Publishing.

14. Germain, L. S. \& Quinn, D. M. (2005). Investigation of Tacit Knowledge in Principal Leadership. The Educational Forum, 70(1), 75-90. http://dx.doi.org/10.1080/00131720508984873

15. Gertler, M. S. (2003). Tacit knowledge and the economic geography of context, or The undefinable tacitness of being (there). Journal of Economic Geography, 3(1), 75-99. http://dx.doi. org $/ 10.1093 / \mathrm{jeg} / 3.1 .75$

16. Haldin-Herrgärd, T. (2000). Difficulties in Diffusion of Tacit Knowledge in Organizations. Journal of Intellectual Capital, 1(4), 357-365. http://dx.doi.org/10.1108/14691930010359252

17. Haldin-Herrgärd, T. (2003). Mapping Tacit Knowledge with “Epitomes". Systèmes d'Information et Management, 8(2), 93-111.

18. Hendrich, W., Mierzwa, R., Heidegger, G., Attwell, G. \& Petersen, W. (2000). Tacit forms of key competences for changing employment opportunities. Flensburg: University Flensburg.

19. Howells, J. (1996). Tacit Knowledge, Innovation and Technology Transfer. Technology Analysis \& Strategic Management, 8(2), 91-106. http://dx.doi.org/10.1080/09537329608524237

20. Hurych, J. B. (n.d.). Manažeř bez manéže. Retrieved from http://hurontaria.baf.cz/BETA/ manazeria.pdf

21. Choi, M. (2001). Assessing Tacit Knowledge - Why and How? Presented at the New Developments in Assessment \& Development' conference, Roffey Park Institute.

22. Janson, A. \& McQueen, R. J. (2007). Capturing Leadership Tacit Knowledge in Conversations with Leaders. Leadership \& Organization Development Journal, 28(7), 646-663. http://dx.doi.org/10.1108/01437730710823897 
23. Jones, B., Failla, A. \& Miller, B. (2007). Tacit Knowledge in Rapidly Evolving Organisational Environments. International Journal of Technology and Human Interaction, 3(1), 49-71. http://dx.doi.org/10.4018/jthi.2007010104

24. Kerr, M. R. (1995). Tacit knowledge as a predictor of managerial success: A field study. Canadian Journal of Behavioural Science/Revue canadienne des sciences du comportement, 27(1), 36-51. http://dx.doi.org/10.1037/0008-400X.27.1.36

25. Kothuri, S. (2002). Knowledge in organizations: definition, creation, harvesting. Knowledge in Organizations. Retrieved October 14, 2003, from http://www.gse.harvard.edu/ t656_ web/Spring_2002_students/kothuri_smita_knowledge_in_orgs.htm

26. Krogh, G. von, Ichijo, K. \& Nonaka, I. (2000). Enabling Knowledge Creation: How to Unlock the Mystery of Tacit Knowledge and Release the Power of Innovation. USA: Oxford University Press.

27. Liao, C.-C. (2005). A Field Study in the Externalising of Tacit Knowledge in On-the-Job Training. International Journal of Management, 22(1), 79-88.

28. Lindley, E. \& Wheeler, F. P. (2001). Using the Learning Square. The Learning Organization, 8(3/4), 114-125. http://dx.doi.org/10.1108/EUM0000000005612

29. Manažer a jeho role 1. (n.d.). (2009, September 13). Retrieved from http://finance.bleskove. net/clanek/manager-a-jeho-role.html\#

30. Matošková, J. (2012). How to Support Knowledge Management through Human Resource Management Activities. International Journal of Knowledge, Culture and Change Management, 11(3), 207-222.

31. Matošková, J. (2008). Formováni tacitnich žnalosti manažerù (dissertation). Zlín (Czech Republic): Tomas Bata University in Zlín.

32. Matthew, C. T. \& Sternberg, R. J. (2009). Developing experience-based (tacit) knowledge through reflection. Learning and Individual Differences, 19(4), 530-540. http://dx.doi. org/10.1016/j.lindif.2009.07.001

33. Mládková, L. (2004). Management żnalosti v praxi. Praha: Professional Publishing.

34. Mládková, L. (2005). Moderníprístupy k managementu: tacitní znalost a jak ji rídit. Praha: Nakladatelství C H Beck.

35. Mládková, L. (2008). Management zunalostních pracovníkio. Praha: Nakladatelství C.H. Beck.

36. Nestor-Baker, N. S. \& Hoy, W. K. (2001). Tacit Knowledge of School Superintendents: Its Nature, Meaning, and Content. Educational Administration Quarterly, 37(1), 86-129. http:// dx.doi.org/10.1177/00131610121969253

37. Österåker, M. (2001). To Put Your Cards on the Table - Collection of Data Through Silent Interviews. Management Decision, 39(7), 578-582. http://dx.doi.org/10.1108/ EUM0000000005806

38. Pacovský, P. (2006). Člověk a čas: time management IV. generace. Praha: Grada Publishing.

39. Penger, S., Znidarsic, J. \& Dimovski, V. (2011). Experiential Learning And Management Education: Empirical Research And Implications For Practice In Higher Education In Slovenia. International Journal of Management and Information Systems, 15(1), 23-34.

40. Prokopenko, J., Spanilý, S., Růžička, J., Kubr, M. \& Jurnečka, S. (1996). Vždělávání a rozvoj manažerü. Praha: Grada Publishing.

41. Průvodce světem povolání - Manažer. (n.d.). Retrieved from http://www.occupationsguide. $\mathrm{cz} / \mathrm{cz} /$ povol/povolani.aspx?Par=1003.htm 
42. Sternberg, R. J. (1997). Managerial Intelligence: Why IQ Isn’t Enough. Journal of Management, 23(3), 475-493. http://dx.doi.org/10.1177/014920639702300307

43. Sternberg, R. J. \& Wagner, R. K. (1992). Tacit Knowledge: An Unspoken Key to Managerial Success. Creativity and Innovation Management, 1(1), 5-13. http://dx.doi.org/10.1111/j.14678691.1992.tb00016.x

44. Sveiby, K. E. (1997). Tacit Knowledge. Retrieved February 18, 2012, from http://www. sveiby.com/articles/Polanyi.html

45. Talisayon, S. D. (2003). Knowledge and People. Business World, 31(1), 12-13.

46. Torff, B. \& Sternberg, R. J. (1998). Changing Mind, Changing World, Practical Intelligence and Tacit Knowledge in Adult Learning. In Adult learning and development: Perspectives from educational psychology (R. Sternberg \& C. M. Smith \& T. Pourchot., pp. 109 - 126). Mahwah, N.J.: Lawrence Erlbaum Associtates.

47. Truneček, J. (2002). Příprava manažerů pro znalostní ekonomiku. Moderní ř́żení, 37(12), 6.

48. Vymětal, J., Diančiková, A. \& Váchová, M. (2005). Informační a zualostní management v praxi. Praha: LexisNexis CZ.

49. Wasonga, T. A. \& Murphy, J. F. (2006). Learning from tacit knowledge: the impact of the internship. The International Journal of Educational Management, 20(2), 153-163. http://dx.doi. org/10.1108/09513540610646136

50. Yeh, Y., Yeh, Y. \& Chen, Y.-H. (2012). From knowledge sharing to knowledge creation: A blended knowledge-management model for improving university students creativity. Thinking Skills and Creativity, 7(3), 245-257. http://dx.doi.org/10.1016/j.tsc.2012.05.004

\section{Contact information}

Ing. Jana Matošková, Ph.D., Ing. Eliške Sobotková, Ing. Martina Polčáková, Ing. Martin Jurásek, doc. PhDr. Ing. Aleš Gregar, CSc.

Tomas Bata University in Zlin, Faculty of Management and Economics

Mostni 5139, 76001 Zlin, Czech Republic

E-mail:matoskova@fame.utb.cz.

Mgr. Helena Řeháčková

University of South Bohemia, Faculty of Education

E-mail:rehackova@fame.utb.cz.

Prof. PhDr. Vlastimil švec, CSc.

Masaryk University, Faculty of Education

E-mail:svec@ped.muni.cr.

JEL Classification: M53 
Appendix I - Fig. 1 - Code links to the code „manager preparation”. Source: own

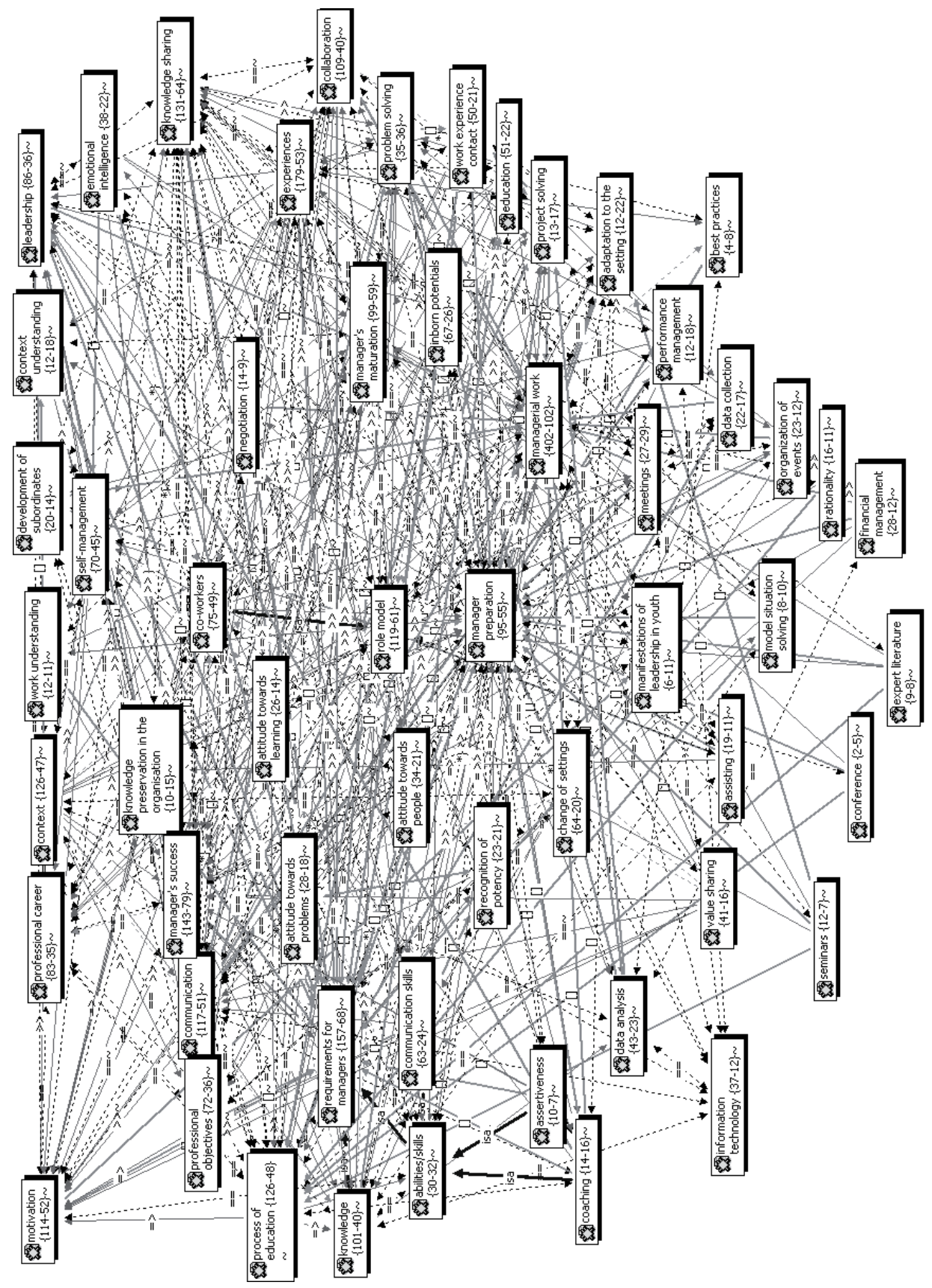




\section{Appendix II - Codes Neighbours to the code "Manager preparation"}

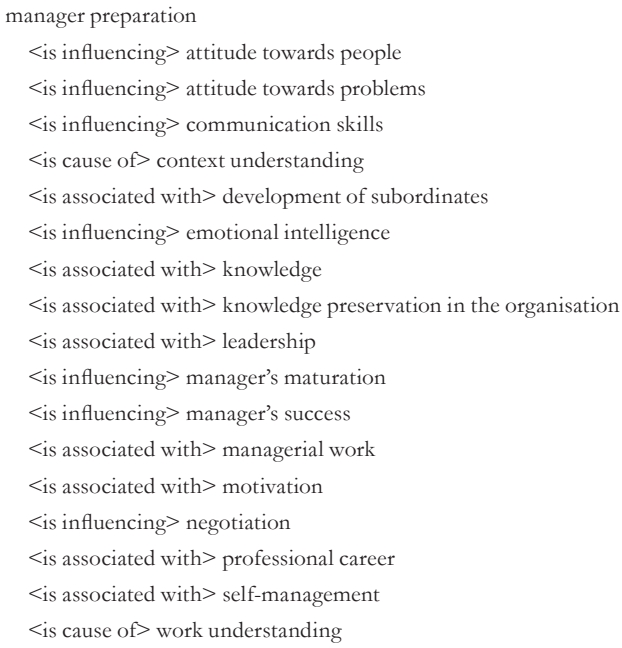

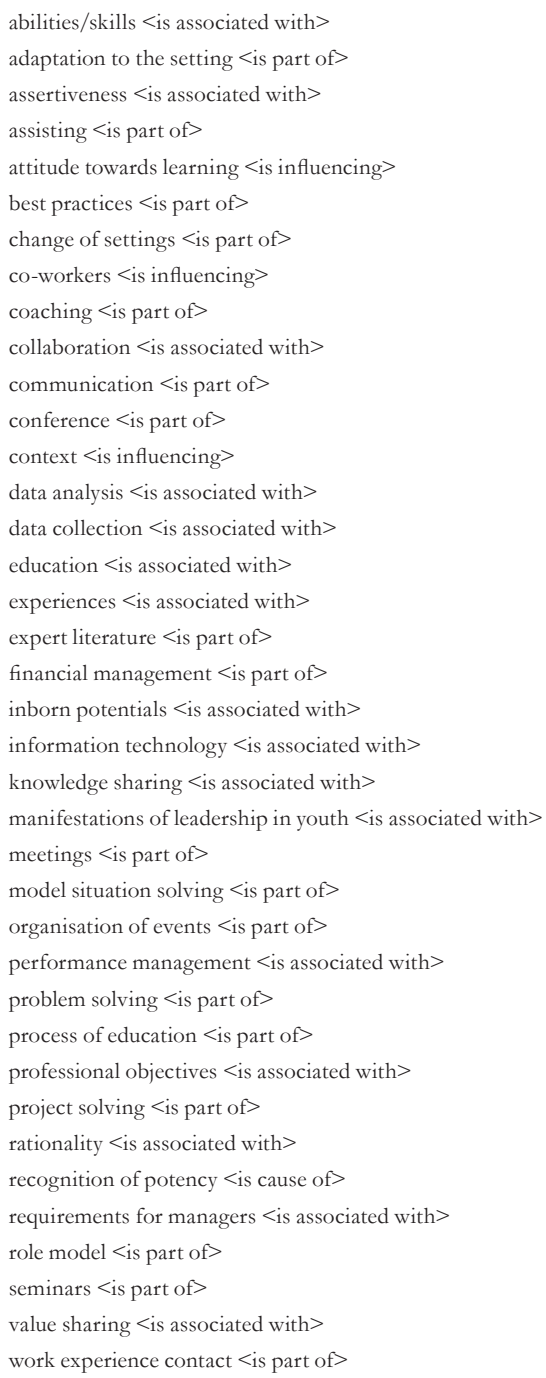

